\title{
Ciprofloxacin triggered glutamate production by Corynebacterium glutamicum
}

\author{
Dorit Lubitz and Volker F. Wendisch ${ }^{*}$
}

\begin{abstract}
Background: Corynebacterium glutamicum is a well-studied bacterium which naturally overproduces glutamate when induced by an elicitor. Glutamate production is accompanied by decreased 2-oxoglutatate dehydrogenase activity. Elicitors of glutamate production by C. glutamicum analyzed to molecular detail target the cell envelope.

Results: Ciprofloxacin, an inhibitor of bacterial DNA gyrase and topoisomerase IV, was shown to inhibit growth of C. glutamicum wild type with concomitant excretion of glutamate. Enzyme assays showed that 2-oxoglutarate dehydrogenase activity was decreased due to ciprofloxacin addition. Transcriptome analysis revealed that this inhibitor of DNA gyrase increased RNA levels of genes involved in DNA synthesis, repair and modification. Glutamate production triggered by ciprofloxacin led to glutamate titers of up to $37 \pm 1 \mathrm{mM}$ and a substrate specific glutamate yield of $0.13 \mathrm{~g} / \mathrm{g}$. Even in the absence of the putative glutamate exporter gene $y g g B$, ciprofloxacin effectively triggered glutamate production. When C. glutamicum wild type was cultivated under nitrogen-limiting conditions, 2-oxoglutarate rather than glutamate was produced as consequence of exposure to ciprofloxacin. Recombinant C. glutamicum strains overproducing lysine, arginine, ornithine, and putrescine, respectively, secreted glutamate instead of the desired amino acid when exposed to ciprofloxacin.

Conclusions: Ciprofloxacin induced DNA synthesis and repair genes, reduced 2-oxoglutarate dehydrogenase activity and elicited glutamate production by C. glutamicum. Production of 2-oxoglutarate could be triggered by ciprofloxacin under nitrogen-limiting conditions.
\end{abstract}

Keywords: Corynebacterium glutamicum, Ciprofloxacin, DNA gyrase, Glutamate, Ornithine, Putrescine, Arginine, Lysine, 2-oxoglutarate, Overflow metabolism

\section{Background}

Glutamic acid and its salts are used as flavor enhancers since decades, due to its "meaty" taste, designated as "umami" [1]. The annual global production of glutamic acid and its salts amounts to about three million tons per year and is still increasing [2]. Corynebacterium glutamicum was discovered because it naturally excretes high amounts of glutamate under certain conditions $[3,4]$. Due to this ability, C. glutamicum and its close relatives are used for the industrial production of glutamate $[2,5]$. This rod shaped, Gram-positive bacterium is biotin auxotrophic and secretes glutamate, for instance when biotin is limiting [4]. Biotin has to be supplemented to the growth media to maintain the function of the two enzymes pyruvate carboxylase (EC

\footnotetext{
* Correspondence: volker.wendisch@uni-bielefeld.de Genetics of Prokaryotes, Faculty of Biology and Center for Biotechnology, Bielefeld University, Universitätsstraße 25, 33615 Bielefeld, Germany
}

6.4.1.1) and acetyl-CoA carboxylase (EC 6.4.1.2) [6, 7]. The second catalyzes the first committed step in fatty acid synthesis [7]. Thus, biotin limitation may be closely connected to changes in the membrane composition. It has also been shown, that glutamate production, induced by biotin limitation, is always accompanied with membrane alteration. However, membrane alterations alone are not a sufficient prerequisite for the production of glutamate [8]. Other membrane destabilizers like detergents (surfactants) or fatty acids like Polyoxyethylen(20)-sorbitan-monopalmitate (Tween-40) and cell wall affecting compounds are used to elicit glutamate production in $C$. glutamicum [9-15]. For example, Penicillin G which inhibits the transpeptidase activity and, thus, cross-linking of cell wall peptidoglycan is a commonly known elicitor of glutamate production by C. glutamicum $[16,17]$. Another antibiotic affecting cell wall synthesis is ethambutol which 
inhibits the arabinosyltransferase, an enzyme involved in the polymerization of cell wall arabinogalactan [18-20].

Although the described elicitors for glutamate production affect the cell envelope of C. glutamicum, it is widely accepted that membrane alteration alone is not sufficient for glutamate production and the 'leak model' is obsolete $[8,21]$. On the one hand, under several glutamate overproducing conditions the metabolic flux is changed, because 2-oxoglutarate dehydrogenase complex (ODHC) activity is reduced [22]. This is contributed to the inhibition of ODHC via OdhI [23, 24]. On the other hand, it is evident that glutamate is not only diffusing through the membrane passively, but involves active export [21, 25]. Recent results affirm that active glutamate export is due to the putative mechanosensitive channel protein YggB [26, 27]. Triggering glutamate overproduction by $C$. glutamicum is a complex phenomenon, but a growth limitation per se (e.g., due to phosphate limitation, [28]) does not lead to glutamate overproduction. It has also been established that triggering export alone is not sufficient for glutamate overproduction [20, 21, 29-31]. However, all known triggers of glutamate overproduction lead to reduced ODHC activity [22, 32-34]. The underlying regulatory mechanism is not transcriptional regulation, but inhibition of ODHC on the enzyme activity level by OdhI, a specific inhibitory protein $[24,35,36]$.

Since the beginning of investigation of glutamate production by C. glutamicum it is known that agents targeting the DNA synthesis can elicit the production of glutamate [37]. Nevertheless, none of these inhibitors of DNA replication were analyzed in C. glutamicum regarding their mode of action in glutamate synthesis. Ciprofloxacin, a member of the fluoroquinolone antibiotics, inhibits DNA gyrase and topoisomerase IV of Gram-negative as well as of Gram-positive bacteria [38, 39]. Therefore, it causes the stagnation of the cell division due to its DNA replication inhibiting function. Here, we report that ciprofloxacin does not only arrest growth of $C$. glutamicum, but also triggers glutamate production.

\section{Results}

\section{Effects of ciprofloxacin on colony formation}

Typically production of a desired metabolite, for instance an amino acid, occurs at the expense of biomass formation. Therefore, arresting growth while maintaining substrate utilization should lead to higher product yields. While sub-lethal concentrations of cell wall active antibiotics such as penicillin $G$ are known to trigger glutamate production by C. glutamicum, the effect of ciprofloxacin, an inhibitor of DNA gyrase and topoisomerase IV in Gram-positive bacteria and, thus, of DNA synthesis [38, 39], on C. glutamicum has not been tested. It is believed that bacterial cells exposed to ciprofloxacin are non-dividing, but living and metabolically active [38].

To determine how ciprofloxacin affects C. glutamicum, cells growing exponentially on glucose minimal medium were exposed to ciprofloxacin for five hours before the colony forming units (cfu) were determined. Growth was arrested already at very low ciprofloxacin concentrations $\left(\mathrm{IC}_{50}=1.3 \mu \mathrm{g} / \mathrm{ml}\right)$, for example at a concentration of $4 \mu \mathrm{g} /$ $\mathrm{ml}$, the ability to form colonies was already reduced by 90 \% (Fig. 1). Colony formation at high ciprofloxacin concentrations was heterogeneous whereas untreated cells formed uniform colonies (see Additional file 1: Figure S1).

\section{Transcriptional effects due to addition of ciprofloxacin}

To determine the transcriptional response of $C$. glutamicum to sub-inhibitory ciprofloxacin concentrations, a microarray experiment was performed for comparison of differential gene expression due to the exposure to ciprofloxacin. Therefore, the C. glutamicum WT was cultured in CGXII and $1 \%(\mathrm{w} / \mathrm{v})$ glucose to an OD600 of about 5 before no or $4 \mu \mathrm{g} \cdot \mathrm{ml}^{-1}$ ciprofloxacin were added for one hour. This relatively low concentration was used, because the growth inhibitory effects are less severe than at higher concentrations. The differential expression of ciprofloxacin treated cells was compared to untreated cells (Table 1). Mostly, genes important for DNA synthesis, repair or modification such as recA (codes for DNA recombinase A), cglIM (codes for DNA cytosine-5methyltransferase) and cg1018 encoding a putative ATPdependent DNA helicase gene showed higher mRNA levels after exposure to ciprofloxacin. This included 8 of the 48

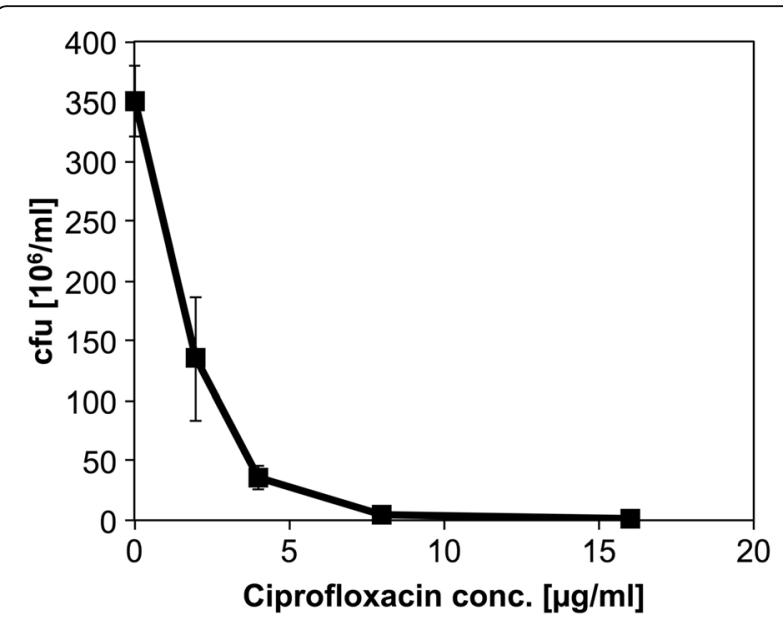

Fig. 1 Colony formation of C. glutamicum wild type in the presence of different ciprofloxacin concentrations. The cells were cultured in CGXII (4 \% (w/v) glucose) to an $\mathrm{OD}_{600}$ of 15 and ciprofloxacin was added. After five hours of ciprofloxacin exposure, cells were diluted in $0.9 \% \mathrm{NaCl}$ to an $\mathrm{OD}_{600}$ of 1 and further diluted. Colony forming units (cfu) were determined. Experiments were performed in biological duplicates and colony number determined for two technical replicates 
Table 1 Differential gene expression of C. glutamicum caused by ciprofloxacin

\begin{tabular}{|c|c|c|c|c|}
\hline Gene $\mathrm{ID}^{\mathrm{a}}$ & Gene name $e^{a}$ & Function of protein ${ }^{a}$ & M-value & $P$-value \\
\hline \multicolumn{5}{|c|}{ DNA synthesis, repair, modification } \\
\hline $\operatorname{cg} 2141$ & recA & Recombinase A & 3.86 & 0.000 \\
\hline cg1996 & cgllM & DNA (cytosine-5-)-methyltransferase & 3.41 & 0.000 \\
\hline $\operatorname{cg} 0886$ & - & Putative ATP-dependent DNA helicase superfamily II & 2.41 & 0.003 \\
\hline $\operatorname{cg} 1401$ & $\operatorname{lig} A$ & DNA ligase $(N A D(+))$ & 2.16 & 0.002 \\
\hline $\operatorname{cg} 1400$ & - & Putative DNA polymerase III, Gram-positive-type alpha subunit & 2.01 & 0.002 \\
\hline $\operatorname{cg} 1997$ & $c g / l R$ & Putative type I| restriction endonuclease & 1.38 & 0.001 \\
\hline $\operatorname{cg} 0885$ & - & Putative helicase, UvrD/Rep-family & 1.08 & 0.029 \\
\hline $\operatorname{cg} 2509$ & reco & DNA repair protein $\mathrm{RecO}$ & 1.05 & 0.044 \\
\hline $\operatorname{cg} 1316$ & - & DNA/RNA helicase, SNF2 family & 1.03 & 0.022 \\
\hline $\operatorname{cg} 1018$ & - & Putative ATP-dependent DNA helicase & 3.12 & 0.001 \\
\hline $\operatorname{cg} 2950$ & $\operatorname{rad} A$ & Putative ATP-dependent protease involved in DNA repair & 1.10 & 0.029 \\
\hline \multicolumn{5}{|c|}{ Transcription, Translation, Proteinmodification } \\
\hline $\operatorname{cg} 2114$ & lexA & transcriptional regulator, LexA-family & 1.61 & 0.004 \\
\hline $\operatorname{cg} 3071$ & pyrE & Orotate phosphoribosyltransferase & 1.38 & 0.025 \\
\hline $\operatorname{cg} 0684$ & papA & Prolyl aminopeptidase A & 1.31 & 0.006 \\
\hline $\operatorname{cg} 0685$ & - & $\begin{array}{l}\text { Conserved hypothetical protein similar to metal-dependent proteases, } \\
\text { putative molecular chaperone }\end{array}$ & 1.66 & 0.003 \\
\hline cg0686 & - & Putative acetyltransferase, GNAT-family & 1.32 & 0.013 \\
\hline $\operatorname{cg} 1980$ & - & Hypothetical protein, MoxR-like ATPase & 1.33 & 0.006 \\
\hline \multicolumn{5}{|c|}{ Genes of unknown function } \\
\hline $\operatorname{cg} 2113$ & divs & Cell division suppressor DivS & 5.38 & 0.000 \\
\hline $\operatorname{cg} 2381$ & - & Conserved hypothetical protein & 3.86 & 0.000 \\
\hline $\operatorname{cg} 1287$ & - & Conserved hypothetical protein & 3.09 & 0.008 \\
\hline $\operatorname{cg} 1962$ & - & Putative membrane protein & 2.56 & 0.000 \\
\hline $\operatorname{cg} 0839$ & - & Hypothetical protein & 2.52 & 0.001 \\
\hline $\operatorname{cg} 1977$ & - & Putative secreted protein & 1.95 & 0.000 \\
\hline cg2026 & - & Hypothetical protein & 1.88 & 0.000 \\
\hline $\operatorname{cg} 1978$ & - & Hypothetical protein & 1.72 & 0.000 \\
\hline $\operatorname{cg} 1917$ & - & Hypothetical protein & 1.50 & 0.002 \\
\hline $\operatorname{cg} 0841$ & - & Conserved hypothetical protein & 1.39 & 0.016 \\
\hline $\operatorname{cg} 1743$ & - & Conserved hypothetical protein & 1.38 & 0.006 \\
\hline $\operatorname{cg} 1937$ & - & Putative secreted protein & 1.22 & 0.015 \\
\hline $\operatorname{cg} 3018$ & - & Hypothetical protein & 1.22 & 0.002 \\
\hline $\operatorname{cg} 0451$ & - & Putative membrane protein & 1.21 & 0.003 \\
\hline $\operatorname{cg} 0712$ & - & Putative secreted protein & 1.08 & 0.014 \\
\hline $\operatorname{cg} 3106$ & - & Conserved hypothetical protein & 1.03 & 0.029 \\
\hline $\operatorname{cg} 2391$ & $\operatorname{aroG}$ & 3-Deoxy-7-phosphoheptulonate synthase & -1.26 & 0.022 \\
\hline cg0203 & iOlE & Putative myo-inosose-2 dehydratase & -1.25 & 0.009 \\
\hline $\operatorname{cg} 1342$ & nar」 & Respiratory nitrate reductase 2 , delta chain & -1.13 & 0.041 \\
\hline $\operatorname{cg} 2378$ & mraZ & Putative MraZ protein & -1.13 & 0.023 \\
\hline $\operatorname{cg} 2118$ & fruR & transcriptional regulator of fructose metabolism & -1.08 & 0.014 \\
\hline cg0205 & iOlH & Myo-inositol catabolism protein & -1.06 & 0.044 \\
\hline
\end{tabular}


Table 1 Differential gene expression of C. glutamicum caused by ciprofloxacin (Continued)

\begin{tabular}{|c|c|c|c|c|}
\hline \multicolumn{5}{|c|}{ Genes of unknown function } \\
\hline $\operatorname{cg} 1918$ & - & Putative secreted protein & -2.82 & 0.000 \\
\hline cg2080 & - & Conserved hypothetical protein & -1.74 & 0.012 \\
\hline $\operatorname{cg} 2952$ & - & Putative secreted protein & -1.58 & 0.002 \\
\hline cg0045 & - & ABC-type putative sugar transporter, permease subunit & -1.36 & 0.025 \\
\hline cg1884 & - & Putative membrane protein & -1.30 & 0.038 \\
\hline $\operatorname{cg} 1340$ & - & Conserved hypothetical protein & -1.27 & 0.001 \\
\hline $\operatorname{cg} 3226$ & - & Putative MFS-type L-lactate permease & -1.15 & 0.009 \\
\hline
\end{tabular}

${ }^{\mathrm{a}}$ Gene ID, gene name and function of proteins are given according to CoryneRegNet (http://coryneregnet.de). ${ }^{\mathrm{b}}$ Relative RNA levels of cells treated with $4 \mu \mathrm{gg} \cdot \mathrm{ml}^{-1}$ ciprofloxacin compared to untreated cells are shown as log 2 values (M-values). ${ }^{*} P$-values were determined by Student's $t$-test. Only genes with significant ( $p<0.05$ ) expression differences and M-values $>1$ or $<1$ are listed. The wild type was cultured in triplicate in CGXII with $1 \%$ (w/v) glucose to an OD 600 of about 5 . Afterwards, cells were exposed to $4 \mu \mathrm{g} / \mathrm{ml}$ ciprofloxacin, a concentration allowing minor growth of the cultures. The data are available as Gene Expression Omnibus GSE77189 data set at http://www.ncbi.nlm.nih.gov/geo/

genes of the LexA regulon [40]. Further genes induced by ciprofloxacin were genes related to transcription, translation or protein modification or unknown functions. Among the genes showing reduced mRNA levels after exposure to ciprofloxacin was the mraZ gene, which putatively is involved in cell division.

\section{Eliciting glutamate production by exposure to ciprofloxacin}

To investigate if a growth arrest due to ciprofloxacin maintains metabolically active C. glutamicum cells, culture supernatants of cells exposed to ciprofloxacin were assayed for amino acids. Interestingly, it was revealed that C. glutamicum produced glutamate when exposed to ciprofloxacin, even though other elicitors of glutamate production were absent from the medium (such as biotin limitation, Penicillin G, ethambutol, Tween 40 $[11,16,19,41])$. Thus, although ciprofloxacin did not affect mRNA levels of genes of glutamate biosynthesis (Table 1), it elicted glutamate production. To identify the optimal ciprofloxacin concentration for triggering glutamate production by $C$. glutamicum WT, different concentrations of ciprofloxacin were added to cultures at an optical density of 15 . It could be shown that even the addition of $2 \mu \mathrm{g} / \mathrm{ml}$ ciprofloxacin elicited the production of glutamate (Fig. 2). The highest glutamate titer was obtained by the addition of $8 \mu \mathrm{g} / \mathrm{ml}$ ciprofloxacin $(37 \pm 1 \mathrm{mM})$ which corresponded to a substrate specific glutamate yield of $0.13 \mathrm{~g} / \mathrm{g}$. This yield is comparable to glutamate production triggered for example by biotin limitation $(0.15 \mathrm{~g} / \mathrm{g})$, addition of ethambutol $(0.2 \mathrm{~g} / \mathrm{g})$ or penicillin $\mathrm{G}(0.25 \mathrm{~g} / \mathrm{g})[19,33,42]$. Since the hitherto known triggers of glutamate production lead to reduced 2-oxoglutarate dehydrogenase complex (ODHC) activity [23, 24], it was analyzed whether the ODHC activity was decreased after exposure to ciprofloxacin. C. glutamicum was cultured in glucose minimal medium to an $\mathrm{OD}_{600}$ of about 8 before either no or $8 \mu \mathrm{g} / \mathrm{L}$ ciprofloxacin were added. ODHC activity was assayed in crude extracts prepared after $4 \mathrm{~h}$ of ciprofloxacin exposure. Indeed, when ciprofloxacin was added, ODHC activity was decreased by $87 \%$ from $5.8 \pm$ $0.7 \mathrm{mU} / \mathrm{mg}$ protein to $0.8 \pm 0.3 \mathrm{mU} / \mathrm{mg}$ protein. These data are comparable to studies with Penicillin G or Tween 40 treated C. glutamicum cells, where the ODHC activities were decreased to a similar extent [22].

Contribution of the mechanosensitive channel protein YggB Besides reduced ODHC activities being involved in glutamate production, active glutamate export is a hallmark of glutamate production by C. glutamicum. The mechanosensitive channel protein MscS encoded by $y g g B$ (cg1432) is involved in the export of glutamate and in its absence glutamate production is reduced about four to five fold [26]. To test whether YggB is important for glutamate production triggered by ciprofloxacin addition, the gene was deleted and glutamate production of the respective strain was measured and compared to

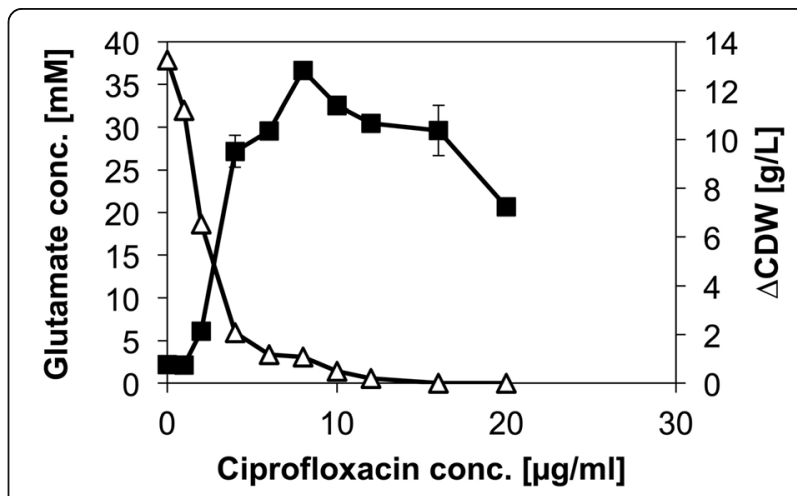

Fig. 2 Biomass formation and glutamate production after ciprofloxacin addition. The C. glutamicum wild type, supplemented with $4 \%(\mathrm{~W} / \mathrm{V})$ glucose, was grown to an optical density of 15 and ciprofloxacin in different concentrations was applied. After ciprofloxacin addition, cultures were incubated until glucose was consumed and the cell dry weight produced in this phase ( $\triangle C D W$, open diamonds) and the glutamate concentration (black squares) were determined, after the consumption of the substrate. Values and error bars represent the mean and the experimental imprecision of duplicates 
the parental strain (Fig. 3). The cells were grown in CGXII (1 \% (w/v) glucose) and ciprofloxacin $(0,4$, and $16 \mu \mathrm{g} / \mathrm{L}$, respectively) was added at an optical density of 2 to 5 . Unexpectedly, ciprofloxacin-induced production of glutamate was observed in the presence and absence of $y g g B$. By contrast, glutamate production under biotin-limiting conditions was decreased about four fold, but not completely abolished (Fig. 3). Thus, unlike for glutamate production under biotin-limiting conditions, ciprofloxacin-triggered glutamate production was not affected by the absence of YggB.

Influence of ciprofloxacin on ornithine, arginine, putrescine and lysine producing strains

In order to test if ciprofloxacin addition triggers production of other glutamate-family amino acids, ornithine and arginine producing strains (ORN1 and ARG1) as well as strain PUT21 producing putrescine, a diamine derived from ornithine, were exposed to ciprofloxacin. The strains were cultured in CGXII supplemented with $1 \%$ (w/v) glucose to an optical density of 2 to 5 before ciprofloxacin was added $(0,4$, and $16 \mu \mathrm{g} / \mathrm{L}$, respectively). However, the addition of ciprofloxacin reduced rather than increased production of ornithine, arginine and putrescine, respectively, and triggered the production of glutamate as by-product (Fig. 4). In a similar experiment, the effect of ciprofloxacin on lysine production by the lysine producing strain DM1729 was determined. Lysine production media have high biotin concentrations (a) to ensure sufficient levels of the biotin protein pyruvate

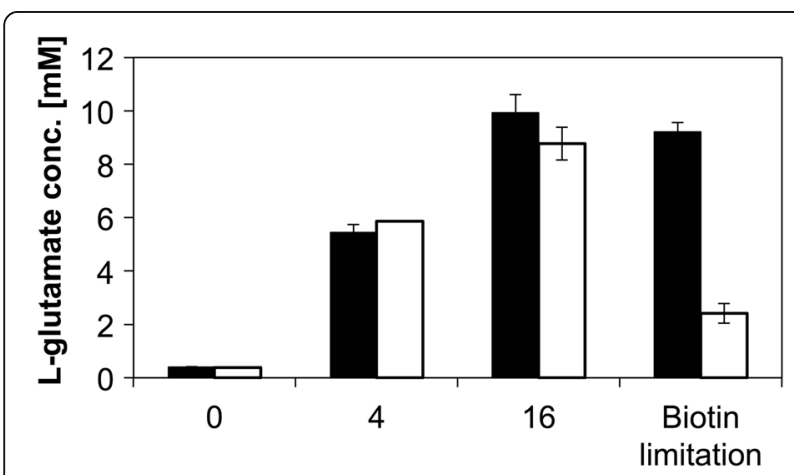

Ciprofloxacin conc. $[\mathrm{\mu g} / \mathrm{ml}]$

Fig. 3 Difference of ciprofloxacin and biotin limitation after yggB deletion. The strains MB001 (black) and MB001 $\triangle y g g B$ (white) were cultured to an optical density of 2 to 5 in CGXII supplemented with $1 \%(\mathrm{~W} / \mathrm{v})$ glucose and ciprofloxacin was applied. In addition, the MB001 strain (black) was compared to MB001 $\triangle y g g B$ (white) during biotin limitation. Therefore the pre-limited cells (in CGXII, $4 \%$ glucose, $0 \mu \mathrm{g}$ biotin per $\mathrm{L}$ ) were re-inocculated to CGXII, containing $2 \mu \mathrm{g}$ biotin per $\mathrm{L}$, supplemented with $1 \%(\mathrm{w} / \mathrm{v})$ glucose. The glutamate concentration of both conditions was determined in the culture supernatant after the complete consumption of glucose. Values and error bars represent the mean and the standard error of triplicate cultivations carboxylase and (b) to avoid glutamate formation triggered by biotin limitation [43]. Addition of ciprofloxacin to the lysine producer resulted in glutamate production and lysine production was reduced at $16 \mu \mathrm{g} / \mathrm{L}$ ciprofloxacin (Fig. 4). Thus, ciprofloxacin addition specifically triggers glutamate production and interferes with production of glutamate-derived products (ornithine, arginine and putrescine) as well as with production of lysine, an amino acid not belonging to the glutamatefamily of amino acids.

\section{Influence of ciprofloxacin on the production of overflow metabolites}

Glutamate may be considered an overflow metabolite, which, however, requires sufficient supply of a nitrogen source. Efficient 2-oxoglutarate production requires deletion of the genes for enzymes converting 2-oxoglutarate to glutamate and nitrogen-limiting conditions [44]. To investigate whether ciprofloxacin triggers 2-oxoglutarate production under nitrogen-liming conditions, C. glutamicum WT was cultivated in CGXII medium containing ten times less nitrogen sources $\left(2 \mathrm{~g}\left(\mathrm{NH}_{4}\right)_{2} \mathrm{SO}_{4}\right.$ and $0.5 \mathrm{~g} / \mathrm{L}$ urea) as compared to regular CGXII medium. Ciprofloxacin $(16 \mu \mathrm{g} / \mathrm{ml})$ was added to the culture, when growth with glucose stagnated due to nitrogen starvation and cultivation was continued until exhaustion of the carbon source. Ciprofloxacin did not affect biomass formation under these conditions, but the product spectrum was changed (Table 2). Instead of glutamate, 2-oxoglutarate was the main product formed (Table 2). Besides $18.6 \pm$ $0.1 \mathrm{mM}$ 2-oxoglutarate, $4 \mathrm{mM}$ glutamate was formed when ciprofloxacin was added while formation of acetate and lactate was not increased by addition of ciprofloxacin (Table 2).

\section{Discussion}

Here, we have characterized how glutamate production by C. glutamicum can be triggered by addition of the gyrase inhibitor ciprofloxacin. In fact, it is known for long that gyrase inhibitors like novobiocin can elicit glutamate efflux in corynebacteria [37]. However, all triggers of glutamate production analyzed to date to some molecular detail have in common to affect the cell membrane and/or cell wall. For example, biotin limitation and addition of the fatty acid synthase inhibitor cerelunin impair fatty acid and/or mycolic acid biosynthesis, penicillin G targets peptidoglycan crosslinking, ethambutol inhibits cell wall arabinogalactan biosynthesis, detergents like Tween 40 impair the surface integrity. The mechanism of ciprofloxacin action with respect to triggering glutamate production remains to be elucidated. In the simplest case, growth arrest by ciprofloxacin maintains metabolic activity of the cells which convert growth substrates to glutamate as 

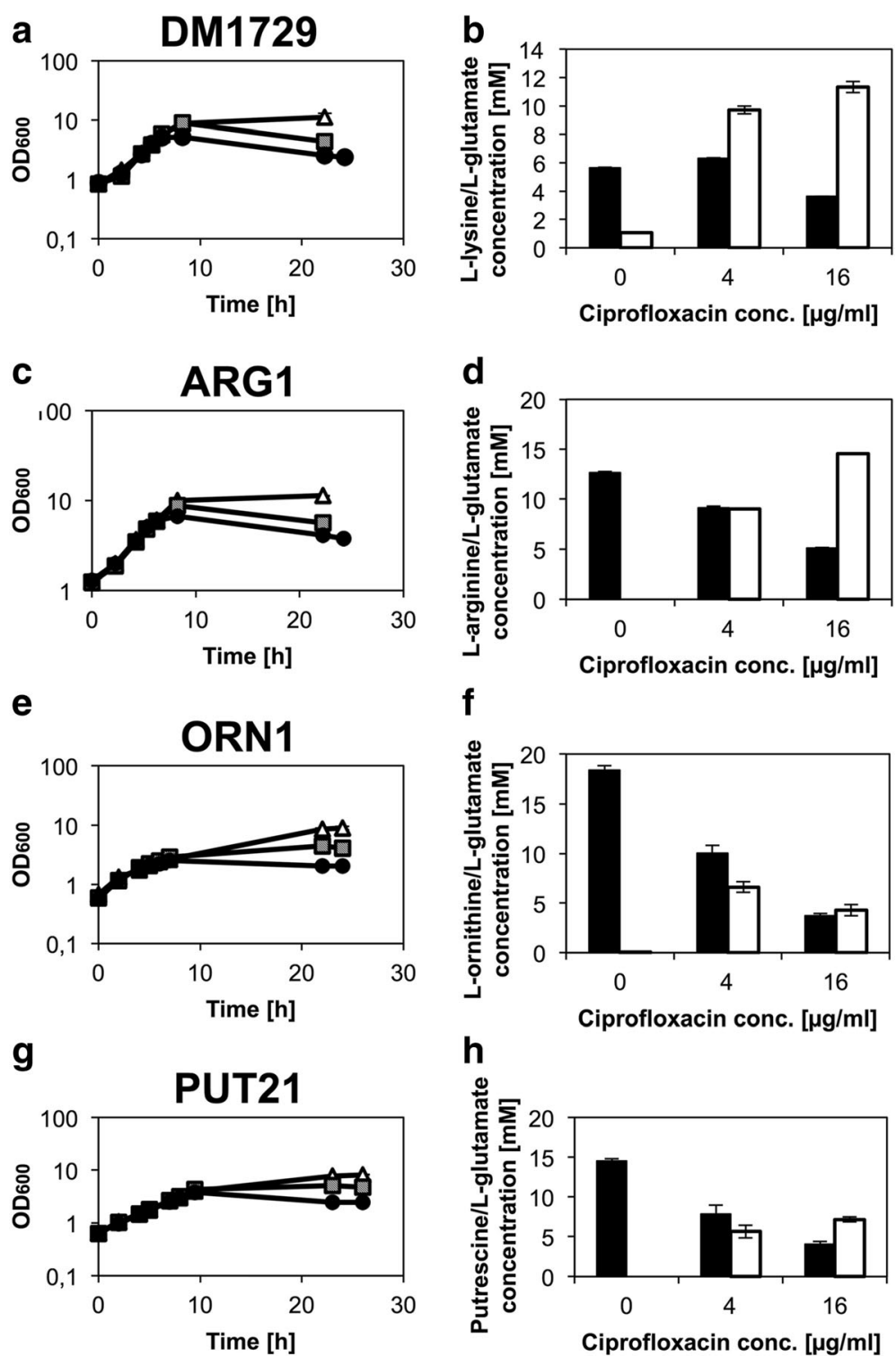

Fig. 4 Growth of amino acid and diamine producer strains exposed to ciprofloxacin. The strains DM1729 (lysine producer) (a + b), ARG1 (arginine producer) $(\mathbf{c}+\mathbf{d})$, ORN1 (ornithine producer) $(\mathbf{e}+\mathbf{f})$ and PUT21 (putrescine producer) $(\mathbf{g}+\mathbf{h})$ were cultured to an optical density of 2 to 5 in CGXIL supplemented with $1 \%(\mathrm{w} / \mathrm{v})$ glucose and ciprofloxacin was applied. Graphs on the left side $(\mathbf{a}, \mathbf{c}, \mathbf{e}, \mathbf{g})$ show the growth inhibition due to the addition of ciprofloxacin in concentrations of $0 \mu \mathrm{g} / \mathrm{ml}$ (white tirangles), $4 \mu \mathrm{g} / \mathrm{ml}$ (hatched squares) and $16 \mu \mathrm{g} / \mathrm{ml}$ (black circles). The graphs on the right side $(\mathbf{b}, \mathbf{d}, \mathbf{f}, \mathbf{h})$ show the concentrations of either lysine, arginine, ornithine or putrescine (black bars) and of glutamate (white bars) after the complete consumption of glucose. Values and error bars represent the mean and the standard error of duplicates

Table 2 Production of organic acids by C. glutamicum WT under nitrogen-limiting conditions in the absence or presence of ciprofloxacin

\begin{tabular}{|c|c|c|c|c|c|}
\hline Ciprofloxacin [mg/ml] & Cell dry weight [mg/ml] & Acetate [mM] & Lactate $[\mathrm{mM}]$ & glutamate [mM] & 2-oxoglutarate [mM] \\
\hline 0 & $6 \pm 1$ & $7 \pm 2$ & $7 \pm 1$ & $0 \pm 1$ & $7 \pm 1$ \\
\hline 16 & $6 \pm 1$ & $10 \pm 1$ & $6 \pm 1$ & $4 \pm 1$ & $19 \pm 1$ \\
\hline
\end{tabular}

Cells were cultivated in CGXII containing ten times less nitrogen sources than regular CGXII medium. 1 \% glucose was used as carbon and energy source. At an $\mathrm{OD}_{600}$ of about 15 , no or $16 \mu \mathrm{g} / \mathrm{ml}$ ciprofloxacin were added. The concentration of organic acids was determined after glucose depletion. All values represent the mean and the standard error of triplicates 
overflow metabolite. This notion is supported by the fact that under nitrogen-limiting conditions 2-oxoglutarate, the immediate nitrogen-free precursor of glutamate is produced instead of glutamate (Table 2).

The exposure of C. glutamicum to ciprofloxacin altered expression of remarkably few genes (Table 1). Genes of glutamate biosynthesis were not significantly altered (Fig. 5). By contrast, one study reported decreased expression of almost all genes involved in the EMP pathway, the PPP, and the TCA cycle by cells triggered for glutamate by addition of detergent, penicillin or by biotin limitation for 12 hs [45]. These expression changes have since been observed when gene expression is compared between slow and fast growing cells [46]. To minimize secondary effects due to long exposures, cells treated with ciprofloxacin were analysed already $1 \mathrm{~h}$ after addition of ciprofloxacin (Table 1). Accordingly, a coherent picture of differential gene expression emerged. The primary transcriptional response to ciprofloxacin targets DNA synthesis as in Streptomyces coelicolor [47]. The response of C. glutamicum to ciprofloxacin showed the typical expression pattern of the SOS response as consequence of DNA damage conditions [40]. Namely the genes $\operatorname{rec} A, \operatorname{cgl} M, \operatorname{cgl} R, \operatorname{rad} A$, $\operatorname{lex} A$ (autoregulation) and $\operatorname{div} S$ and several genes of unknown function (cg2381, cg2026, cg0841, cg1977) of the 48 genes of the LexA regulon were upregulated. As known

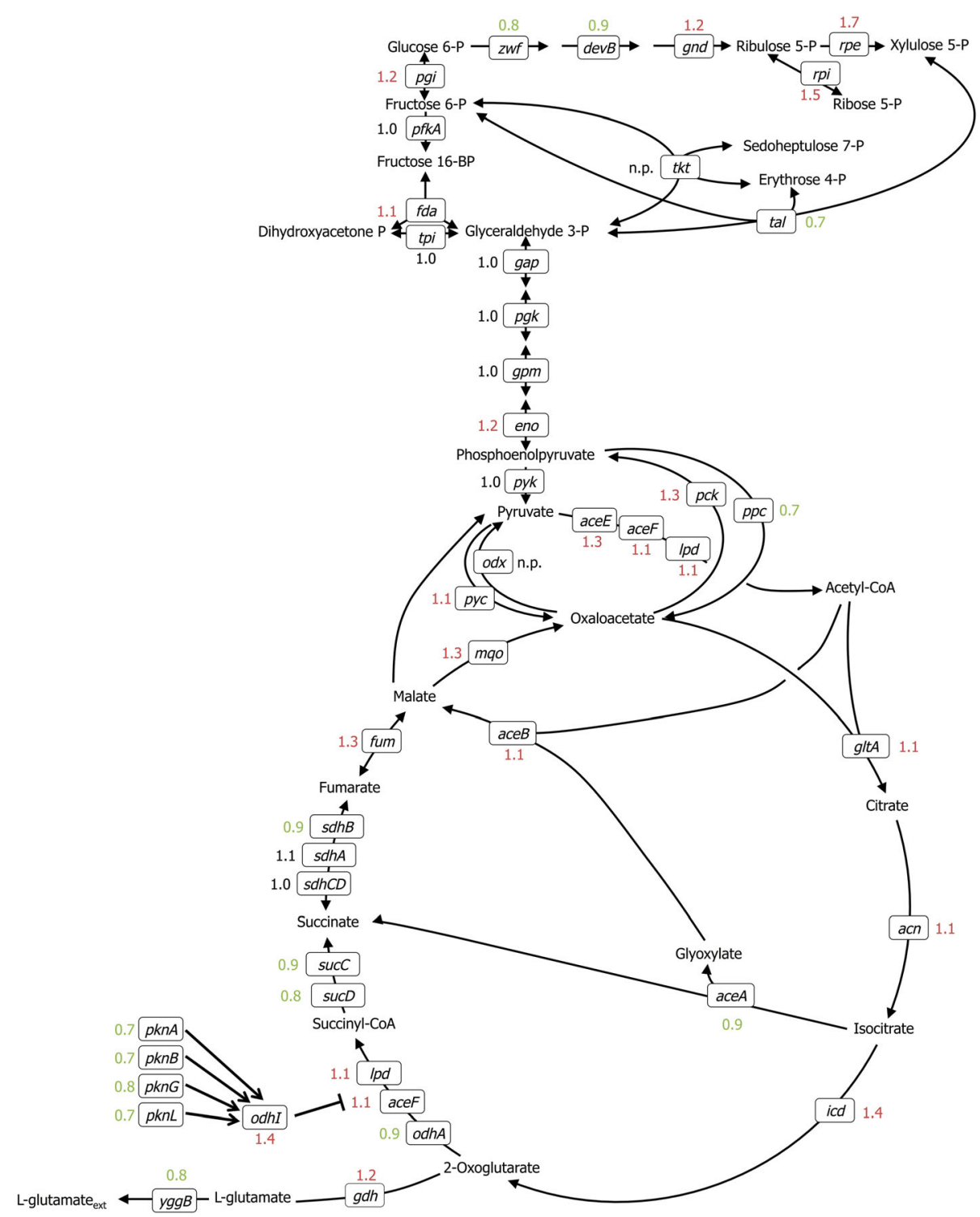

Fig. 5 Scheme of the central carbon metabolism and glutamate biosynthesis and relative RNA levels with/without ciprofloxacin treatment. Genes are depicted next to the reaction catalyzed by the encoded enzymes. Relative RNA levels of cells treated with $4 \mu \mathrm{g} / \mathrm{ml}$ ciprofloxacin compared to untreated cells are shown (values in green are below 1, those in red greater than 1), however, unlike the genes listed in Table 2, none of the genes depicted here showed significantly changed expression as determined by Student's t-test, i.e., $p>0.05$. 6PGL: 6-phosphogluconolactone; 6PG: 6-phosphogluconat 
for C. glutamicum and other bacteria, autoproteolytic cleavage of the transcriptional regulator LexA is induced by RecA bound to single stranded DNA leading to the induction of the LexA regulon [48-51]. Several genes of the LexA regulon [40] were induced by ciprofloxacin in $C$. glutamicum. Notably, the LexA regulon was induced in $E$. coli by nalidixic acid, which is a gyrase inhibitor of the class of quinoles as ciprofloxacin [52]. Transcriptional regulation by LexA is not a prerequisite of glutamate production in C. glutamicum since induction of the LexA regulon has not been reported when glutamate production was triggered by biotin limitation or by addition of ethambutol or tween $40[45,53]$. When C. glutamicum was treated with high ciprofloxacin concentrations, very few colony forming units were observed and these showed colony heterogeneity as depicted in Additional file 1: Figure S1 for $100 \mu \mathrm{g} / \mathrm{ml}$ ciprofloxacin, a concentration about 60 fold higher than $\mathrm{IC}_{50}$. Likely, mutations have occurred leading to different ciprofloxacin susceptibility as is often observed for treatments triggering the LexA regulon and the SOS response [54].

Genome resequencing of glutamine-producing E. coli mutants obtained by classical mutagenesis and screening revealed nonsynonymous mutations in $g y r A$ which encodes the primary target of ciprofloxacin DNA gyrase and these mutations were shown to have caused glutamine overproduction and reduction of chromosomal DNA supercoils [55]. Similarly, overexpression of genes encoding topoisomerase I (topA) and topoisomerase IV ( $p a r C$ and parE) reduced chromosomal DNA coils and entailed glutamine production by E. coli [55]. MurI-type glutamate racemases are known to inhibit DNA gyrase activity in E. coli [56] and Bacillus subtilis [57]. These enzymes link DNA gyrase activity to murein biosynthesis since Dglutamate is present in peptidoglycan cross-links. As the closely related $C$. diphtieriae possesses D-glutamate in its tetrapeptides (L-Ala-D-Glu-meso-Dap-D-Ala) and tripeptides (L-Ala-D-Glu-meso-Dap) of peptidoglycan [58], it is likely that D-glutamate is also present in the peptidoglycan peptides of $C$. glutamicum. In fact, $C$. glutamicum possesses a murI gene [59]. However, excretion of D-amino acids by C. glutamicum has not been observed unless a heterologous racemase gene was overexpressed [60]. Altered murein biosynthesis and cell wall integrity due to ciprofloxacin may be involved in triggering glutamate production under these conditions.

Exposure to ciprofloxacin triggered glutamate production even in strains overproducing other amino acids such as lysine as it is true for penicillin G-triggered glutamate production [16]. Thus, ciprofloxacin is a specific trigger of glutamate production by C. glutamicum. Glutamate was also produced efficiently in the absence of $y g g B$ coding for the glutamate channel, which releases glutamate by passive diffusion [61]. By contrast, the deletion of $y g g B$ reduced, but not completely abolished glutamate production triggered by biotin limitation (see also Fig. 3) or Penicillin G [26, 62]. The residual glutamate production in the absence of YggB varied from trigger to trigger, but suggested that (an) additional glutamate export system(s) may exist. This is supported by the fact, that the export of glutamate is also observed when the external concentration exceeds the intracellular concentration, which suggests an additional energydependent transport mechanism [63].

Triggers of glutamate production are known to elicit a metabolic switch in the sense that ODHC activity is reduced [23, 24], and also ciprofloxacin reduced ODHC activity about seven fold (see above). The reduced ODHC activity in the presence of ciprofloxacin may also explain ciprofloxacin-triggered production of 2-oxoglutarate under nitrogen-limiting conditions (Table 2). Other triggers of glutamate production also led to 2-oxoglutarate production under nitrogen-limiting conditions $[44,64,65]$. When ace $A$ (encoding isocitrate lyase), gltB (encoding glutamate-2-oxoglutarate aminotransferase) and $g d h$ (encoding glutamatate dehydrogenase) were disrupted in addition, 2-oxoglutarate production was improved 16 fold and almost $50 \mathrm{~g} / \mathrm{L} 2$-oxoglutarate accumulated [65].

\section{Conclusions}

Glutamate production by C. glutamicum triggered by ciprofloxacin was characterized and shown not to be affected by the absence of the putative glutamate export system YggB. This gyrase inhibitor led to increased expression of genes that are involved in DNA synthesis, repair and modification and belong to the LexA regulon and SOS response of C. glutamicum. The exact mechanism(s) of triggering glutamate production by ciprofloxacin and other previously published triggers in C. glutamicum remain(s) enigmatic. However, as observed with all published triggers of glutamate production, ciprofloxacin reduced ODHC activity in C. glutamicum. Moreover, production of 2-oxoglutarate could be triggered by ciprofloxacin under nitrogen-limiting conditions.

\section{Methods}

\section{Microorganisms and growth conditions}

Microorganisms and plasmids used in this study are listed in Table 3. E. coli DH5 $\alpha$ was used for gene cloning. C. glutamicum and E. coli strains were routinely grown in lysogeny broth (LB) $(10 \mathrm{~g} / \mathrm{L}$ tryptone, $5 \mathrm{~g} / \mathrm{L}$ yeast extract, $10 \mathrm{~g} / \mathrm{L}$ sodium chloride) in $500 \mathrm{~mL}$ baffled flasks on a rotary shaker $(120 \mathrm{rpm})$ or LB agar plates $(18 \mathrm{~g} / \mathrm{L}$ agar $)$ at $30^{\circ} \mathrm{C}$ or $37^{\circ} \mathrm{C}$. For growth experiments, CGXII minimal medium [66] was used for $C$. glutamicum. Growth was followed by measuring the optical density at $600 \mathrm{~nm}$ using a V-1200 Spectrophotometer (VWR, Radnor, PA, USA). An $\mathrm{OD}_{600}$ of 1 
Table 3 Strains and plasmids used in this study

\begin{tabular}{|c|c|c|}
\hline \multicolumn{3}{|l|}{ E. coli strains } \\
\hline $\mathrm{DH} 5 \mathrm{a}$ & 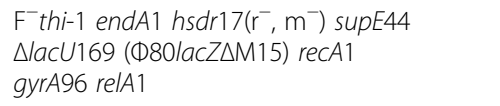 & [74] \\
\hline \multicolumn{3}{|c|}{ C. glutamicum strains } \\
\hline WT & $\begin{array}{l}\text { Wild type strain ATCC13032, auxotrophic } \\
\text { for biotin }\end{array}$ & ATCC \\
\hline MB001 & $\begin{array}{l}\text { ATCC } 13032 \text { with in-frame deletion } \\
\text { of prophages CGP1 (cg1507-cg1524), } \\
\text { CGP2 (cg1746-cg1752), and CGP3 } \\
\text { (cg1890-cg2071) }\end{array}$ & [75] \\
\hline ARG1 & $\begin{array}{l}\text { WT with in-frame deletion of } \triangle a r g R \\
\text { carrying the pEKEx-arg } B^{\text {fbr }} \text { vector }\end{array}$ & [76] \\
\hline ORN1 & WT with in-frame deletion of $\triangle \arg F R$ & [76] \\
\hline DM1729 & WT with lys $C^{\mathrm{P} 458 \mathrm{~S}}$, hom ${ }^{\mathrm{V} 59 \mathrm{~A}}$, pyc $\mathrm{C}^{\mathrm{T3111}}$ & [70] \\
\hline PUT21 & $\begin{array}{l}\text { WT with in-frame deletion of } \triangle a r g F R \\
\text { carrying the pWWEx1-speC-argF leaky vector }\end{array}$ & [77] \\
\hline MB001 $\triangle y g g B$ & MB001 with in-frame deletion of $\Delta y g g B$ & This study \\
\hline \multicolumn{3}{|l|}{ Plasmids } \\
\hline pK19mobsacB & $\begin{array}{l}\text { Kan', mobilizable E. coli vector for the } \\
\text { construction of insertion and deletion } \\
\text { mutants of C. glutamicum (oriv, sacB, lacZ) }\end{array}$ & [78] \\
\hline $\mathrm{pK} 19 \Delta y g g B$ & $\begin{array}{l}K^{K}{ }^{R}, \text { pk19mobsacB with the deletion } \\
\text { construct of gene yggB }\end{array}$ & This study \\
\hline
\end{tabular}

corresponds approximately to an estimated cell dry weight of $0.25 \mathrm{~g} / \mathrm{L}$.

When necessary, the growth medium was supplemented with kanamycin $(25 \mu \mathrm{g} / \mathrm{mL})$, spectinomycin (100 $\mu \mathrm{g} / \mathrm{mL})$, isopropyl $\beta$-D-1-thiogalactopyranoside (IPTG) $(1 \mathrm{mM})$ and arginine $(750 \mu \mathrm{M})$. The growth behavior, amino acid and organic acid production and the substrate consumption of C. glutamicum strains were analyzed in $500 \mathrm{ml}$ baffled flasks. Briefly, a $50 \mathrm{~mL}$ BHI $(37 \mathrm{~g} / \mathrm{L})$ seed culture was inoculated from an agar plate and cultivated overnight. The cells were harvested by centrifugation (4,000 x g, $10 \mathrm{~min}$ ) and washed twice with CGXII minimal medium without carbon source. Subsequently, $50 \mathrm{~mL}$ CGXII medium, containing a given concentration of carbon source and necessary supplements, was inoculated to an optical density of 1.0. Detailed information on the carbon source and nitrogen concentrations employed is given in the results chapter.

\section{Determination of ODHC activity}

Cultivation of the C. glutamicum wild type was performed in CGXII (4\% glucose) and ciprofloxacin was added at an $\mathrm{OD}_{600}$ of 10 . After $4{ }^{\circ} \mathrm{C}$, the cells were harvested and immediately, crude extracts were isolated by ultrasonic treatment and the fresh extracts were analyzed as described before [67].

\section{Molecular genetic techniques}

Standard methods such as restriction digestions, and ligation were carried out as described elsewhere [68]. Digested DNA was purified by using the QIAquick Gel Extraction Kit (Qiagen, Hilden, Germany). E. coli cells were transformed by heat shock [68] and C. glutamicum cells were transformed by electroporation [66]. Isolation of genomic DNA was performed as previously described [69]. Chromosomal changes in C. glutamicum were performed as described elsewhere [66]. The gene for the putative glutamate exporter was deleted in MB001 pK19mobsacB $\Delta y g g B$. Flanks of yggB were amplified and joined by crossover-PCR with primers yggB_up_fw + yggB_up_rw and yggB_dw_fw + yggB_dw_rv (italics: restriction sites, underlined: homologous sequence; yggB_up_fw, CTTGAATTCGGACCCGTCCAAGCCAAG (EcoRI); ygg B_up_rw, AGAGACGACCTAAGCCAGTCTGGGTACG CCTAAAATCATGAGC; yggB_dw_fw, AGACTGGCTT AGGTCGTCTCTGTCCAAGAGACAGTTGCGCC; yggB _dw_rv, CCTCTGCAGGGAAGGGAGTTGAAGGTGA CG (PstI)). The crossover PCR prodcut was restricted with EcoRI and PstI and ligated into EcoRI and PstI restricted pK19mobSacB. The primers yggB_up (CTTTTGGCGCT CCAAGTACT) and yggB_down (TCCTCGAGCGATCG AACAAT) were used for confirmation of the by PCR amplification and DNA sequencing.

\section{Determination of amino acid and carbohydrate concentrations}

For the quantification of extracellular amino acids and carbohydrates, a high-performance liquid chromatography system was used (1200 series, Agilent Technologies Deutschland GmbH, Böblingen, Germany). Samples were withdrawn from the cultures, centrifuged $(13,000 \mathrm{x}$ g, $10 \mathrm{~min}$ ), and the supernatant used for analysis.

Organic acids were analyzed on a normal phase column (organic acid resin $300 \times 8 \mathrm{~mm}, 10 \mu \mathrm{m}$ particle size, $25 \AA$ Å pore diameter; Chromatographie Service $\mathrm{GmbH}$, Langerwehe, Germany) using $5 \mathrm{mM}$ sulfuric acid as the mobile phase at a flow rate of $1 \mathrm{~mL} \mathrm{~min}^{-1}$ and were detected with a refractive index detector (RID G1362A, 1200 series, Agilent Technologies). Amino acids were automatically modified by precolumn derivatisation with ortho-phthalaldehyde and separated as described previously [70]. ornithine, lysine and glutamate were quantified using a pre-column (LiChrospher 100 RP18 EC-5 $\mu$ (40 x $4 \mathrm{~mm})$, CS-Chromatographie Service GmbH, Langerwehe, Germany) and a reversed phase column (LiChrospher 100 RP18 EC-5 $\mu$ (125 x 4 mm), CS Chromatographie) as a main column and detected with a fluorescence detector at excitation at $230 \mathrm{~nm}$ and $450 \mathrm{~nm}$ emission (FLD G1321A, 1200 series, Agilent Technologies). For the determination of arginine and putrescine, a reverse-phase (RP) LiChrospher 100 RP8 
EC-5 $\mu$ precolumn $(40 \times 4.6 \mathrm{~mm})$ and a RP8 EC-5 $\mu$ (125 x $4.6 \mathrm{~mm})$ main column (CS Chromatographie, Langerwehe, Germany) were used. $100 \mu \mathrm{M}$ L-asparagine was used as an internal standard. The mobile phases used were in case of RP8 A: $0.25 \%$ Na-acetate $\mathrm{pH}$ 6, B: methanol. The gradient used was: 0 min $30 \% \mathrm{~B}, 1 \mathrm{~min}$ $30 \% \mathrm{~B}, 6 \mathrm{~min}, 70 \% \mathrm{~B}, 11 \min 90 \% \mathrm{~B}, 14 \min 70 \% \mathrm{~B}$, 16 min $30 \% \mathrm{~B}$. In case of RP18, the mobile phases used were A:0.1 M Na-acetate $\mathrm{pH} 7.2$, B: methanol. The gradient used was: $0 \mathrm{~min} 20 \% \mathrm{~B}, 0.5 \mathrm{~min} 38 \% \mathrm{~B}, 2.5 \mathrm{~min}$ $46 \% \mathrm{~B}, 3.7 \min 65 \% \mathrm{~B}, 5.5 \min 70 \% \mathrm{~B}, 6 \min 75 \% \mathrm{~B}$, $6.2 \min 85 \%$ B, $6.7 \min 20 \%$ B.

\section{Transcriptome analysis using DNA microarrays}

The C. glutamicum wild type was exposed to $4 \mu \mathrm{g} / \mathrm{ml}$ ciprofloxacin to enable growth of the cells and compared to the untreated wild type. The cells were inoculated in CGXII (4\% (w/v) glucose), ciprofloxacin was added at an $\mathrm{OD}_{600}$ of 5 and the RNA was isolated after one hour of ciprofloxacin exposure. Fluorescently labeled cDNA synthesis and DNA microarray hybridization was performed as described previously $[71,72]$. The data was analyzed as described previously [73]. The data were normalized using the LOWESS approach. The significance of gene expression rates was determined using a $t$-test adjusted with the False Discovery Rate approach. Furthermore, the adjusted $p$-value had to be lower than 0.05 and the genes needed to be regulated more than two-fold. The data are available as Gene Expression Omnibus GSE77189 data set at http://www.ncbi.nlm.nih.gov/geo/.

\section{Additional file}

Additional file 1: Figure S1. Colony formation of C. glutamicum wild type without ciprofloxacin $(0 \mathrm{\mu g} / \mathrm{ml})$ and with the addition of $100 \mathrm{\mu g} / \mathrm{ml}$ to the medium. (DOCX $968 \mathrm{~kb}$ )

\section{Abbreviations}

cfu: Colony forming units; Msc: Mechanosensitive channel protein

ODHC: 2-oxoglutarate dehydrogenase complex

\section{Acknowledgements}

We thank Jaide V. K. Jensen for construction of the Plasmid pK19 $\Delta y g g B$.

\section{Funding}

This work was partially supported by the program ZIM (grant. no. KF2969003SB2). We acknowledge support for the Article Processing Charge by the Deutsche Forschungsgemeinschaft and the Open Access Publication Fund of Bielefeld University.

\section{Availability of data and materials}

The transcriptomics data are available as Gene Expression Omnibus GSE77189 data set at http://www.ncbi.nlm.nih.gov/geo/.

Figure S1 is attached and depicts colony formation of C. glutamicum wild type without and after the addition of $100 \mu \mathrm{g} / \mathrm{ml}$ ciprofloxacin.

\section{Authors' contributions}

VFW and DL planned and designed the experiments. DL performed the experiments. VFW and DL analyzed the data. DL drafted the manuscript. VFW finalized the manuscript. Both authors read and approved the manuscript.

\section{Competing interests}

The authors declare that they have no competing interests.

\section{Consent for publication}

Not applicable.

Ethics approval and consent to participate

Not applicable.

Received: 19 May 2016 Accepted: 1 October 2016

Published online: 07 October 2016

References

1. Kawamura Y. Umami: a basic taste. Physiology, biochemistry, nutrition, food science. New York: Marcel Dekker; 1987.

2. Wendisch VF, Eberhardt D, Jensen JVK, Herbst M. Amino Acids and Nucleotides. In: Biotechnological Production of Natural Ingredients for Food Industry. Edited by Bicas J. Sharjah: Bentham Science Publishers; 2016. p. 60-163.

3. Kinoshita S, Udaka S, Shimono M. Studies on the amino acid fermentation. Production of L-glutamic acid by various microorganisms. J Gen Appl Microbiol. 1957;3:193-205.

4. Udaka S. Screening method for microorganisms accumulating metabolites and its use in the isolation of Micrococcus glutamicus. J Bacteriol. 1960;79:745-55.

5. Ikeda M. Amino acid production processes. Adv Biochem Eng Biotechnol. 2003;79:1-35

6. Peters-Wendisch PG, Kreutzer C, Kalinowski J, Patek M, Sahm H, Eikmanns BJ. Pyruvate carboxylase from Corynebacterium glutamicum: characterization, expression and inactivation of the pyc gene. Microbiol. 1998;144(Pt 4):915-27.

7. Jäger W, Peters-Wendisch PG, Kalinowski J, Pühler A. A Corynebacterium glutamicum gene encoding a two-domain protein similar to biotin carboxylases and biotin-carboxyl-carrier proteins. Arch Microbiol. 1996; 166(2):76-82.

8. Hoischen C, Krämer R. Membrane alteration is necessary but not sufficient for effective glutamate secretion in Corynebacterium glutamicum. J Bacteriol. 1990:172(6):3409-16

9. Takinami K, Tsunoda T, Okada H. Biochemical effects of fatty acid and its derivatives on L-glutamic acid fermentation. 1. Accumulation of L-glutamic acid in presence of sucrose fatty acid ester. Agr Biol Chem. 1963;27(12):858-63.

10. Takinami K, Okada H, Tsunoda T. Biochemical effects of fatty acid and its derivatives on L-glutamic acid fermentation. 2. Effective chemical structure of fatty acid derivatives on accummlation of L-glutamic acid in biotin sufficient medium. Agr Biol Chem. 1964;28(2):114-9.

11. Takinami $\mathrm{K}$, Yoshii $\mathrm{H}$, Tsuri $\mathrm{H}, \mathrm{Okada} \mathrm{H}$. Biochemical effects of fatty acid and its derivatives on L-glutamic acid fermentation. 3. Biotin-Tween 60 relationship in accumulation of L-glutamic acid and growth of Brevibacterium lactofermentum. Agr Biol Chem. 1965:29(4):351-9.

12. Takinami $K$, Yamada $Y$, Okada H. Biochemical effects of fatty acid and its derivatives on L-glutamic acid fermentation. 4. Biotin content of growing cells of Brevibacterium lactofermentum. Agr Biol Chem. 1966;30(7):674-82.

13. Takinami K, Yamada Y, Okada H. Biochemical effects of fatty acid and its derivatives on L-glutamic acid fermentation. 5. Dualistic property of oleic acid and synergetic effect of saturated fatty acid. Agr Biol Chem. 1967:31(2):223-8.

14. Takinami K, Yoshii H, Yamada Y, Okada H, Kinoshita K. Control of L-glutamic acid fermentation by biotin and fatty acid. Amino Acid Nucl Acid. 1968; 183:120-60

15. Duperray F, Jezequel D, Ghazi A, Letellier L, Shechter E. Excretion of glutamate from Corynebacterium glutamicum triggered by amine surfactants. Biochim Biophys Acta. 1992;1103(2):250-8.

16. Nara T, Kinoshita S, Samejima H. Effect of penicillin on amino acid fermentation Agr Biol Chem. 1964;28(2):120-4.

17. Walsh CT. Enzymes in the D-alanine branch of bacterial cell wall peptidoglycan assembly. J Biol Chem. 1989;264(5):2393-6.

18. Belanger AE, Besra GS, Ford ME, Mikusova K, Belisle JT, Brennan PJ, Inamine JM. The embAB genes of Mycobacterium avium encode an arabinosyl transferase involved in cell wall arabinan biosynthesis that is the target for the antimycobacterial drug ethambutol. Proc Natl Acad Sci U S A. 1996;93(21):11919-24

19. Radmacher E, Stansen KC, Besra GS, Alderwick L, Maughan WN, Hollweg G, Sahm H, Wendisch VF, Eggeling L. Ethambutol, a cell wall inhibitor of Mycobacterium tuberculosis, elicits L-glutamate efflux of Corynebacterium glutamicum. Microbiol. 2005;151(Pt 5):1359-68. 
20. Daffé M. The Cell Envelope of Corynebacteria. In: Handbook of Corynebacterium glutamicum. Edited by Eggeling L, Bott M. Boca Raton: CRC Press; 2005. p. 121-148.

21. Kimura E. Glutamate production. In: Handbook of Corynebacterium glutamicum. Edited by Eggeling L, Bott M. CRC Press; 2005. p. 439-465.

22. Kawahara Y, Takahashi-Fuke K, Shimizu E, Nakamatsu T, Nakamori S. Relationship between the glutamate production and the activity of 2-oxoglutarate dehydrogenase in Brevibacterium lactofermentum. Biosci Biotech Bioch. 1997;61(7):1109-12.

23. Niebisch A, Kabus A, Schultz C, Weil B, Bott M. Corynebacterial protein kinase G controls 2-oxoglutarate dehydrogenase activity via the phosphorylation status of the Odhl protein. J Biol Chem. 2006;281(18):12300-7.

24. Schultz C, Niebisch A, Gebel L, Bott M. Glutamate production by Corynebacterium glutamicum: dependence on the oxoglutarate dehydrogenase inhibitor protein Odhl and protein kinase PknG. Appl Microbiol Biot. 2007;76(3):691-700.

25. Hoischen C, Krämer R. Evidence for an efflux carrier system involved in the secretion of glutamate by Corynebacterium glutamicum. Arch Microbiol. 1989;151(4):342-7.

26. Nakamura J, Hirano S, Ito H, Wachi M. Mutations of the Corynebacterium glutamicum NCgl1221 gene, encoding a mechanosensitive channel homolog, induce L-glutamic acid production. Appl Environ Microbiol. 2007;73(14):4491-8.

27. Hashimoto K, Nakamura K, Kuroda T, Yabe I, Nakamatsu T, Kawasaki H. The protein encoded by NCg/1221 in Corynebacterium glutamicum functions as a mechanosensitive channel. Biosci Biotechnol Biochem. 2010;74(12):2546-9.

28. Ishige T, Krause M, Bott M, Wendisch VF, Sahm H. The phosphate starvation stimulon of Corynebacterium glutamicum determined by DNA microarray analyses. J Bacteriol. 2003;185(15):4519-29.

29. Shimizu H, Hirasawa T. Production of glutamate and glutamate-related amino acids: Molecular mechanism analysis and metabolic engineering. In: Amino Acid Biosynthesis - Pathways, Regulation and Metabolic Engineering. Edited by Wendisch VF, vol. 5. Micobiol Monogr. Berlin Heidelberg: Springer-Verlag; 2007.

30. Eggeling L. Structure and Synthesis of the Cell Wall. In: Corynebacteria: Genomics and Molecular Biology. Edited by Burkovski A. Norfolk: Caister Academic Press; 2008. p. 267-294

31. Ikeda M, Takeno S: Amino Acid Production by Corynebacterium glutamicum. In: Corynebacterium glutamicum - Biology and Biotechnology. Microbiology Monographs. Edited by Yukawa H. Inui M, vol. 23. Berlin Heidelberg: Springer Verlag; 2013. p. 107-147.

32. Shimizu H, Tanaka H, Nakato A, Nagahisa K, Kimura E, Shioya S. Effects of the changes in enzyme activities on metabolic flux redistribution around the 2-oxoglutarate branch in glutamate production by Corynebacterium glutamicum. Bioprocess Biosyst Eng. 2003;25(5):291-8.

33. Kim J, Fukuda H, Hirasawa T, Nagahisa K, Nagai K, Wachi M, Shimizu H. Requirement of de novo synthesis of the Odhl protein in penicillin-induced glutamate production by Corynebacterium glutamicum. Appl Microbiol Biotechnol. 2010;86(3):911-20.

34. Kim J, Hirasawa T, Sato Y, Nagahisa K, Furusawa C, Shimizu H. Effect of odhA overexpression and odhA antisense RNA expression on Tween-40-triggered glutamate production by Corynebacterium glutamicum. Appl Microbiol Biotechnol. 2009;81(6):1097-106.

35. Kim J, Hirasawa T, Saito M, Furusawa C, Shimizu H. Investigation of phosphorylation status of Odhl protein during penicillin- and Tween 40-triggered glutamate overproduction by Corynebacterium glutamicum. Appl Microbiol Biotechnol. 2011;91(1):143-51.

36. Schultz C, Niebisch A, Schwaiger A, Viets U, Metzger S, Bramkamp M, Bott M. Genetic and biochemical analysis of the serine/threonine protein kinases PknA, PknB, PknG and PknL of Corynebacterium glutamicum: evidence for non-essentiality and for phosphorylation of Odhl and FtsZ by multiple kinases. Mol Microbiol. 2009;74(3):724-41.

37. Phillips T, Somerson NL. Production of glutamic acid. US 3080297 A. 1963.

38. Drlica K, Zhao XL. DNA gyrase, topoisomerase IV, and the 4-quinolones. Microbiol Mol Biol Rev. 1997;61(3):377-92.

39. Pommier $\mathrm{Y}$, Leo E, Zhang HL, Marchand C. DNA Topoisomerases and Their Poisoning by Anticancer and Antibacterial Drugs. Chem Biol. 2010;17(5):421-33.

40. Jochmann N, Kurze AK, Czaja LF, Brinkrolf K, Brune I, Huser AT, Hansmeier N, Puhler A, Borovok I, Tauch A. Genetic makeup of the Corynebacterium glutamicum LexA regulon deduced from comparative transcriptomics and in vitro DNA band shift assays. Microbiol. 2009;155(Pt 5):1459-77.
41. Kinoshita S, Udaka S, Akita S. Method of producing L-glutamic acid by fermentation. In., vol. US 3003925 A. 1961

42. Sato H, Orishimo K, Shirai T, Hirasawa T, Nagahisa K, Shimizu H, Wachi M. Distinct roles of two anaplerotic pathways in glutamate production induced by biotin limitation in Corynebacterium glutamicum. J Biosci Bioeng. 2008; 106(1):51-8.

43. Peters-Wendisch P, Stansen KC, Götker S, Wendisch VF. Biotin protein ligase from Corynebacterium glutamicum: role for growth and L-lysine production. Appl Microbiol Biotechnol. 2012;93(6):2493-502.

44. Lee YB, Jo JH, Kim MH, Lee HH, Hyun HH. Enhanced production of alphaketoglutarate by fed-batch culture in the metabolically engineered strains of Corynebacterium glutamicum. Biotechnol Bioproc Eng. 2013;18(4):770-7.

45. Kataoka M, Hashimoto Kl, Yoshida M, Nakamatsu T, Horinouchi S, Kawasaki H. Gene expression of Corynebacterium glutamicum in response to the conditions inducing glutamate overproduction. Lett Appl Microbiol. 2006:42(5):471-6.

46. Silberbach M, Burkovski A. Application of global analysis techniques to Corynebacterium glutamicum: New insights into nitrogen regulation. J Biotechnol. 2006;126(1):101-10.

47. Patkari M, Mehra S. Transcriptomic study of ciprofloxacin resistance in Streptomyces coelicolor A3(2). Mol Biosyst. 2013:9(12):3101-16.

48. Brent R, Ptashne M. Mechanism of action of the lexA gene product. Proc Natl Acad Sci U S A. 1981;78(7):4204-8.

49. Walker GC. Mutagenesis and inducible responses to deoxyribonucleic acid damage in Escherichia coli. Microbiol Rev. 1984;48(1):60-93.

50. Little JW. Mechanism of specific LexA cleavage: autodigestion and the role of RecA coprotease. Biochimie. 1991;73(4):411-21.

51. Butala M, Zgur-Bertok D, Busby SJ. The bacterial LexA transcriptional repressor. Cell Mol Life Sci. 2009;66(1):82-93.

52. Sassanfar M, Roberts JW. Nature of the SOS-inducing signal in Escherichia coli. The involvement of DNA replication. J Mol Biol. 1990;212(1):79-96.

53. Stansen KC. Charakterisierung der Ausscheidung von L-Glutamat bei Corynebacterium glutamicum. Schriften des Forschungszentrums Jülich Reihe Lebenswissenschaften / Life Sciences. 2005:22.

54. McKenzie GJ, Harris RS, Lee PL, Rosenberg SM. The SOS response regulates adaptive mutation. Proc Natl Acad Sci U S A. 2000;97(12):6646-51.

55. Hayashi M, Tabata K. Metabolic engineering for L-glutamine overproduction by using DNA gyrase mutations in Escherichia coli. Appl Environ Microbiol. 2013;79(9):3033-9.

56. Ashiuchi M, Kuwana E, Yamamoto T, Komatsu K, Soda K, Misono H. Glutamate racemase is an endogenous DNA gyrase inhibitor. J Biol Chem. 2002; 277(42):39070-3.

57. Ashiuchi M, Kuwana E, Komatsu K, Soda K, Misono H. Differences in effects on DNA gyrase activity between two glutamate racemases of Bacillus subtilis, the poly-gamma-glutamate synthesis-linking Glr enzyme and the YrpC (Murl) isozyme. FEMS Microbiol Lett. 2003;223(2):221-5.

58. Kato K, Stroming J, Kotani S. Structure of cell wall of Corynebacterium diphtheriae.l. Mechanism of hydrolysis by $L-3$ enzyme and structure of peptide. Biochemistry. 1968;7(8):2762-73.

59. Malathi KC, Wachi M, Nagai K. Isolation of the murl gene from Brevibacterium lactofermentum ATCC 13869 encoding D-glutamate racemase. FEMS Microbiol Lett. 1999;175(2):193-6.

60. Stäbler N, Oikawa T, Bott M, Eggeling L. Corynebacterium glutamicum as a host for synthesis and export of D-Amino Acids. J Bacteriol. 2011;193(7):1702-9.

61. Hashimoto K, Murata J, Konishi T, Yabe I, Nakamatsu T, Kawasaki H. Glutamate is excreted across the cytoplasmic membrane through the NCg/1221 channel of Corynebacterium glutamicum by passive diffusion. Biosci Biotech Bioch. 2012;76(7):1422-4

62. Becker M, Börngen K, Nomura T, Battle AR, Marin K, Martinac B, Krämer R. Glutamate efflux mediated by Corynebacterium glutamicum MscCG, Escherichia coli MscS, and their derivatives. Biochim Biophys Acta. 2013; 1828(4):1230-40.

63. Gutmann M, Hoischen C, Kramer R. Carrier-mediated glutamate secretion by Corynebacterium glutamicum under biotin limitation. Biochim Biophys Acta. 1992;1112(1):115-23.

64. Shiio I, Mitsugi K, Tsunoda T. Bacterial formation of glutamic acid from acetic acid in the growing culture medium. J Biochem. 1959;46(12):1665-6.

65. Jo JH, Seol HY, Lee YB, Kim MH, Hyun HH, Lee HH. Disruption of genes for the enhanced biosynthesis of alpha-ketoglutarate in Corynebacterium glutamicum. Can J Microbiol. 2012;58(3):278-86. 
66. Eggeling L, Reyes O: Experiments. In: Handbook of Corynebacterium glutamicum. Edited by Eggeling L, Bott M. Boca Raton: CRC Press; 2005. p. 3535-3566.

67. Hoffelder M, Raasch K, van Ooyen J, Eggeling L. The E2 domain of OdhA of Corynebacterium glutamicum has succinyltransferase activity dependent on lipoyl residues of the acetyltransferase AceF. J Bacteriol. 2010;192(19):5203-11.

68. Sambrook J, Russell D. Molecular Cloning. A Laboratory Manual, 4th Edition. Cold Spring Harbor: Cold Spring Harbor Laboratoy Press; 2012.

69. Jensen JV, Wendisch VF. Ornithine cyclodeaminase-based proline production by Corynebacterium glutamicum. Microb Cell Fact. 2013;12:63.

70. Georgi T, Rittmann D, Wendisch VF. Lysine and glutamate production by Corynebacterium glutamicum on glucose, fructose and sucrose: Roles of malic enzyme and fructose-1,6-bisphosphatase. Metab Eng. 2005;7(4):291-301.

71. Polen T, Schluesener D, Poetsch A, Bott M, Wendisch VF. Characterization of citrate utilization in Corynebacterium glutamicum by transcriptome and proteome analysis. FEMS Microbiol Lett. 2007;273(1):109-19.

72. Wendisch VF. Genome-wide expression analysis in Conynebacterium glutamicum using DNA microarrays. J Biotechnol. 2003;104(1-3):273-85.

73. Lessmeier $L$, Wendisch VF. Identification of two mutations increasing the methanol tolerance of Conynebacterium glutamicum. Bmc Microbiol. 2015;15:216

74. Hanahan D. Studies on transformation of Escherichia coli with plasmids. J Mol Biol. 1983;166(4):557-80.

75. Baumgart M, Unthan S, Rückert C, Sivalingam J, Grunberger A, Kalinowski J, Bott M, Noack S, Frunzke J. Construction of a prophage-free variant of Corynebacterium glutamicum ATCC 13032 for use as a platform strain for basic research and industrial biotechnology. Appl Environ Microbiol. 2013; 79(19):6006-15.

76. Schneider J, Niermann K, Wendisch VF. Production of the amino acids L-glutamate, L-lysine, L-ornithine and L-arginine from arabinose by recombinant Conynebacterium glutamicum. J Biotechnol. 2011;154(2-3):191-8.

77. Schneider J, Eberhardt D, Wendisch VF. Improving putrescine production by Corynebacterium glutamicum by fine-tuning ornithine transcarbamoylase activity using a plasmid addiction system. Appl Microbiol Biotechnol. 2012; 95(1):169-78.

78. Schäfer A, Tauch A, Jäger W, Kalinowski J, Thierbach G, Pühler A. Small mobilizable multi-purpose cloning vectors derived from the Escherichia coli plasmids pK18 and pK19: selection of defined deletions in the chromosome of Corynebacterium glutamicum. Gene. 1994;145(1):69-73.

\section{Submit your next manuscript to BioMed Central and we will help you at every step:}

- We accept pre-submission inquiries

- Our selector tool helps you to find the most relevant journal

- We provide round the clock customer support

- Convenient online submission

- Thorough peer review

- Inclusion in PubMed and all major indexing services

- Maximum visibility for your research

Submit your manuscript at www biomedcentral.com/submit

) Biomed Central 